\title{
Interpersonal Communication in Family Planning in Pakistan*
}

\author{
M. NASEEM IQBal FAROOQUI
}

\section{INTRODUCTION}

In order to curb the harmful effects of population growth many developing countries initiated family planning programmes around the year 1960 . These programmes traditionally consisted of two components namely provision of family planning services on the supply side and Information, Education and Communication (IEC) on the demand side. In many of these countries the IEC component has been performing functions such as providing information about the locations and types of services available and motivating couples to adopt family planning. Besides, IEC has also been performing the function of educating the local and national leaders and educated people about population problems and benefits of smaller family size [Rogers (n.d.)]. The channels through which IEC messages are conveyed are either mass media or interpersonal communication. Mass media includes television, radio, and print media. Planned interpersonal channels include person to person contacts by home visitors etc. Whereas unplanned interpersonal communication consists of exchanges between husband and wife, among relatives and friends.

Interpersonal communication between husband and wife has assumed greater importance owing to the fact that it modifies the behaviour of the couples towards the adoption of family planning methods. Husband-wife communication development may take place through the frequency and intensity of family planning messages on electronic media, through personal motivation by family planning workers and through interpersonal communication with friends, relatives and neighbours etc. Besides, husband's favourable attitude towards family planning plays a dominant role in the development of interpersonal communication between husband and wife towards the adoption of contraceptive methods. received.

-Owing to unavoidable circumstances, the discussant's comments on this paper have not been Islamabad.

M. Naseem Iqbal Farooqui is Senior Fellow at the National Institute of Population Studies, 
In a family planning communication study conducted in Pakistan [Rukanuddin et al. (1988)], 63.8 percent of currently married female contraceptive acceptors attributed husband-wife communication as the specific source for motivation to adopt family planning. On the other hand 29.5 percent contraceptive users reported interpersonal communication with friends, relatives and neighbours as the specific source for motivation to adopt family planning. On the basis of these findings, Pakistan Family Planning Programme has placed special emphasis on the development of interpersonal communication during the Eighth Five-Year Plan [Government of Pakistan (1993)].

\section{OBJECTIVE OF THE STUDY}

Because of the importance of husband-wife communication in the adoption of family planning methods it becomes imperative to examine the correlates of husband-wife communication in Pakistan. These correlates may include the sociodemographic characteristics of the respondents, their residential status, husband's attitude towards family planning and respondents exposure to family planning messages through the electronic media. Last but not least husband's own favourable attitude towards family planning could exert a positive impact on the development of effective husband-wife communication in family planning in regard to the adoption of family planning programmes as well as the desire of a certain number of children in the family.

\section{DATA SOURCE AND METHODOLOGY}

Data derives all its variables under study from the national level Pakistan Demographic and Health Survey undertaken during 1990-91 [National Institute of Population Studies (1993)]. The survey was based on national probability samples of clusters randomly distributed across the four provinces of Pakistan and its regions namely major urban, semi urban and rural areas. All the currently married women aged 15-49 years were asked questions on socio-demographic characteristics, KAP, and health status etc. Besides, questions on husband-wife communication were also specified which included (a) How often have you and your husband talked about family planning in the past, and (b) Have you and your husband ever discussed the number of children you would like to have. In addition questions in regard to respondent's exposure to electronic media in family planning messages were also asked which included "Have you heard a family planning message on radio" as well as "Have you heard a family planning message on TV". In addition the husband's attitude toward family planning was also inquired through "Does your husband 
approve couples using a family planning method". Bivariate and multivariate regression techniques are used to examine the determinants of interpersonal communication.

\section{ANALYSIS OF RESULTS CROSS TABULATIONS}

To examine the two-way relationship between family planning communication and selected socio-demographic variables as well as communication variables, a series of basic cross-tabulations were run separately for 6393 currently married women from the Pakistan Demographic and Health Survey data. The interpersonal communication variables were 'discussion of family planning with husbands' and 'discussion of desired number of children with husbands'. The socio-demographic variables were wife's current age, level of education, number of living children and work status. The communication variables were whether wife had heard family planning message on radio or TV. Positive attitude of husband towards family planning was represented by husbands approval for couples using family planning method.

Couples usually discuss family planning among themselves either when they are on the verge of using contraceptives or when they tend to use contraceptives either very soon or in the distant future. A situation may arise in which a partner may be in urgent need of using a contraceptive or may like to use contraception in the future while the other partner may not like to use contraception.

In this survey no question has been asked as to after how many children the couples discussed family planning. However for purposes of this paper only, emphasis is placed on the relationship between interpersonal communication and other socio-demographic and communication variables. Approximately 22 percent (Table 1) of the wives in Pakistan reported that they had discussed family planning with their husbands but of these 16.8 percent had discussed family planning once or twice and 5.1 percent more often (not given in the Table). More often discussion about family planning is considered to be a prime motivator of family planning. In urban areas $\mathbf{2 8 . 5}$ percent of the women discussed family planning with their husbands, out of which $\mathbf{2 1 . 5}$ percent of the women discussed family planning with their husbands, once or twice and 7 percent more often. In rural areas 15 percent of the women discussed family planning with their husbands, out of which 11.8 percent discussed once or twice and 3.2 percent more often. It may be observed that the level and frequency of interpersonal communication in Pakistan is quite small keeping in view the fact that Pakistan, since 1965 has been running a well-established national family planning programme. 


\section{Table 1}

Percent of Currently Married Women Discussed Family Planning and Number of Children by Socio-demographic and Communication Variables, PDHS 1990-91

\begin{tabular}{|c|c|c|c|}
\hline & Characteristic & $\begin{array}{l}\text { Discussed Family } \\
\text { Planning with } \\
\text { Husband }\end{array}$ & $\begin{array}{c}\text { Discussed Number } \\
\text { of Children } \\
\text { with Husband }\end{array}$ \\
\hline & Total & 21.9 & 33.1 \\
\hline . & $\begin{array}{l}\text { Current Age } \\
15-19 \\
20-24 \\
25-29 \\
30-34 \\
40-44 \\
45-49\end{array}$ & $\begin{array}{l}14.2 \\
21.1 \\
24.2 \\
25.5 \\
24.9 \\
19.6\end{array}$ & $\begin{array}{l}28.4 \\
35.0 \\
38.3 \\
35.6 \\
34.2 \\
26.8\end{array}$ \\
\hline 2. & $\begin{array}{l}\text { Level of Education* } \\
\text { No Schooling } \\
\text { Primary } \\
\text { Middle } \\
\text { Secondary } \\
\text { Higher }\end{array}$ & $\begin{array}{l}17.3 \\
30.2 \\
38.5 \\
40.4 \\
48.2\end{array}$ & $\begin{array}{l}26.7 \\
43.2 \\
51.3 \\
65.5 \\
66.1\end{array}$ \\
\hline 3. & $\begin{array}{l}\text { Number of Living Childrer } \\
0 \\
1 \\
2 \\
3 \\
4 \\
5 \\
6+\end{array}$ & $\begin{array}{l}10.6 \\
17.9 \\
22.8 \\
22.9 \\
26.2 \\
25.7 \\
24.2\end{array}$ & $\begin{array}{l}29.3 \\
35.4 \\
37.6 \\
34.5 \\
37.1 \\
34.7 \\
28.0\end{array}$ \\
\hline 4. & $\begin{array}{l}\text { Residentlal Status* } \\
\text { Major City } \\
\text { Small City } \\
\text { Rural }\end{array}$ & $\begin{array}{l}33.0 \\
23.3 \\
15.0\end{array}$ & $\begin{array}{l}49.6 \\
32.9 \\
24.1\end{array}$ \\
\hline 5. & $\begin{array}{l}\text { Women Work Status } \\
\text { Currently Working } \\
\text { Working not Working }\end{array}$ & $\begin{array}{l}24.9 \\
24.7\end{array}$ & $\begin{array}{l}40.6 \\
31.8\end{array}$ \\
\hline 6. & $\begin{array}{l}\text { Desire More Children } \\
\text { Desire no More Children }\end{array}$ & $\begin{array}{l}12.7(4152) \\
35.7(2241)\end{array}$ & $\begin{array}{l}34.7(2670) \\
42.3(2417)\end{array}$ \\
\hline 7. & $\begin{array}{l}\text { Heard Family Planning } \\
\text { Message on Radio* } \\
\text { Yes } \\
\text { No }\end{array}$ & $\begin{array}{l}30.8 \\
19.5\end{array}$ & $\begin{array}{l}43.9 \\
30.3\end{array}$ \\
\hline 8. & $\begin{array}{l}\text { Heard Family Planning M } \\
\text { Yes } \\
\text { No }\end{array}$ & $\begin{array}{l}34.4 \\
18.3\end{array}$ & $\begin{array}{l}48.8 \\
28.7\end{array}$ \\
\hline 9. & $\begin{array}{l}\text { Hushand Approves Couple } \\
\text { Pamily Planning Method } \\
\text { Yes } \\
\text { No }\end{array}$ & $\begin{array}{r}47.3 \\
9.2\end{array}$ & $\begin{array}{l}57.1 \\
21.2\end{array}$ \\
\hline
\end{tabular}

- Chi Square Significant at 0.05 level. 
The proportion of wives who said they discussed family planning with their husbands was negatively related to women's age. Younger women tended to discuss family planning more with their husbands. The rate increased slowly from its lowest level in the initial phase to the highest level in fertile age groups, then declined first slowly and then rapidly till reaching its lowest in terminal age group. The proportion of wives who said they discussed family planning with their husbands was positively related to women's age. In other words, younger and more educated women were more likely than others to discuss family planning issues with their husbands. Number of living children of a women is also one of the determinants of family planning adoption. Very few women with no or one living child ever discussed family planning with their husbands and they do in fact practice contraception for purposes of spacing only. Proportion of women discussing family planning increases rapidly from two living children and reaches the maximum for four living children. Thereafter they decline slowly till reaching a minimum for $\mathbf{6}$ and more living children.

Women residing in major cities tended to discuss more ( 33 percent) with their husbands as compared to those residing in small cities (23.3 percent) and in rural areas (15 percent). No worthwhile difference is observed between the women working and not working outside the home in regard to their family planning behaviour. Significant difference for family planning was observed in regard to the desire of more children. Only 12.7 percent women desiring more children discussed family planning with their husbands as compared to 35.7 percent who desired no more children.

Exposure to electronic media showed positive association with family planning behaviour. Women who heard family planning messages on radio and T.V. were significantly more likely to discuss family planning with their husbands as compared to those who were not exposed to such messages.

Similarly women who discussed desired number of children were found to be young and more educated and were more likely than others to discuss desired number of children with their husbands. On the whole 33 percent of the women in Pakistan, 49.6 percent in major cities, 32.9 percent in small cities and 24.1 percent in rural areas have discussed the number of children with their husbands. The discussion tended to increase curvilinearly with number of living children with maximum attained at parity four. No worthwhile difference was observed for women's employment outside the home.

Women who desired no more children were more likely than others to have such discussion where as women whose husbands bore favourable attitude towards family planning were significantly more likely than others to engage in such discus- 
sion. Exposure to family planning messages through the electronic media tended to affect more the likelihood of the desired number of children.

\section{MULTIVARIATE LOGISTIC REGRESSION ANALYSIS}

The results discussed in the previous paragraphs pertained to simple bivariate analysis. The model under examination (Table 2) shows that older women are significantly less likely than others to discuss family planning with their husbands. Similarly, women with middle and higher level of education tend to significantly discuss more with their husbands. Similarly women with 2, 3 and 4 and more living children had more significant discussion as compared to those who had one or no living children. Keeping other factors constant desire for no more children exerted significantly positive impact on the initiation of family planning discussion.

Husbands approval for family planning is more than three times more likely to induce a woman to initiate family planning dialogue with her husband. As compared to the rural areas women in major cities are significantly more likely to have a constructive dialogue with their husbands in regard to the adoption of family planning techniques. Exposure to family planning messages on television exert a positive impact on the modification of reproductive behaviour.

In the foregoing analysis it has been observed that socio-demographic and communication variables exert a significant impact in inducing couples to adopt family planning as an end. LOGISTIC regression analysis on desired number of children indicates that socio-demographic, attitudinal and communication variables exert a significant impact on the desire for a certain number of children.

\section{CONCLUSION}

The study was designed to examine as to how far socio-demographic characteristics of currently married women as well as the family planning message on the electronic media along with husband's attitude towards family planning affect husband-wife communication in regard to the adoption of family planning techniques. The study brings to light the fact that the changes in husband's attitude as well as exposure to family planning messages in the media along with women's level of education are the prime determinants of generating interpersonal communication between husband and wife in regard to family planning. The family planning programme of Pakistan has therefore laid great emphasis on the generation of inter-personal communication for the successful implementation of its Eighth FiveYear Plan. 
Table 2

Likelihood of Wifes Discussing Family Planning and Number of Children with Husbands by Socio-demographic and Communication Variables; Results of Multivariate Logistic Regression Analysis, PDHS 1990-91

\begin{tabular}{|c|c|c|c|c|c|}
\hline & & $\begin{array}{l}\text { Discuss } \\
\text { Planning }\end{array}$ & $\begin{array}{l}\text { Family } \\
\text { h Husband }\end{array}$ & $\begin{array}{l}\text { Discuss } \\
\text { Children }\end{array}$ & $\begin{array}{l}\text { Number of } \\
\text { th Husband }\end{array}$ \\
\hline & Characteristics & $\begin{array}{l}\text { Odds } \\
\text { Ratio }\end{array}$ & $\begin{array}{c}\text { Wald } \\
\text { Statistics }\end{array}$ & $\begin{array}{l}\text { Odds } \\
\text { Ratio }\end{array}$ & $\begin{array}{c}\text { Wald } \\
\text { Statistics }\end{array}$ \\
\hline & $\begin{array}{l}\text { Current Age } \\
15-29 \\
30-39 \\
40-49\end{array}$ & $\begin{array}{l}1.00 \\
0.88 \\
0.47^{*}\end{array}$ & $\begin{array}{r}\overline{1.63} \\
32.46\end{array}$ & $\begin{array}{l}1.00 \\
0.97 \\
0.53^{*}\end{array}$ & $\begin{array}{r}\overline{0.08} \\
22.61\end{array}$ \\
\hline 2. & $\begin{array}{l}\text { Level of Education } \\
\text { No Schooling } \\
\text { Primary } \\
\text { Middle + }\end{array}$ & $\begin{array}{l}1.00 \\
1.20 \\
1.68^{*}\end{array}$ & $\begin{array}{r}\overline{2} .01 \\
22.20\end{array}$ & $\begin{array}{l}1.00 \\
1.14 \\
2.32^{*}\end{array}$ & $\begin{array}{r}\overline{1.20} \\
57.43\end{array}$ \\
\hline 3. & $\begin{array}{l}\text { Number of Living Children } \\
0-1 \\
2-3 \\
4+\end{array}$ & $\begin{array}{l}1.00 \\
1.51^{*} \\
1.91^{*}\end{array}$ & $\begin{array}{l}\overrightarrow{11.81} \\
24.03\end{array}$ & $\begin{array}{l}1.00 \\
1.08 \\
1.22^{*}\end{array}$ & $\begin{array}{l}- \\
0.53 \\
2.37\end{array}$ \\
\hline 4. & $\begin{array}{l}\text { Desire for Children } \\
\text { More Children } \\
\text { No More Children }\end{array}$ & $\begin{array}{l}1.00 \\
1.75^{*}\end{array}$ & $\overline{28.15}$ & $\begin{array}{l}1.00 \\
1.25^{*}\end{array}$ & $\overline{3.43}$ \\
\hline 5. & $\begin{array}{l}\text { Husband Approves Family } \\
\text { Planning } \\
\text { Disapproves } \\
\text { Approves }\end{array}$ & $\begin{array}{l}1.00 \\
3.57^{*}\end{array}$ & 224.02 & $\begin{array}{l}1.00 \\
2.57^{*}\end{array}$ & $\overline{158.40}$ \\
\hline 6. & $\begin{array}{l}\text { Exposed to Family Planning } \\
\text { Message on Radio } \\
\text { Not Exposed } \\
\text { Exposed }\end{array}$ & $\begin{array}{l}1.00 \\
1.15\end{array}$ & $\overline{1.37}$ & $\begin{array}{l}1.00 \\
1.14\end{array}$ & $\overline{1.35}$ \\
\hline 7. & $\begin{array}{l}\text { Exposed to Family Planning } \\
\text { Message on TV } \\
\text { Not Exposed } \\
\text { Exposed }\end{array}$ & $\begin{array}{l}1.00 \\
1.30^{*}\end{array}$ & $\overline{6.73}$ & $\begin{array}{l}1.00 \\
1.27^{*}\end{array}$ & $\overline{4.25}$ \\
\hline 8. & $\begin{array}{l}\text { Residential Status } \\
\text { Rural } \\
\text { Small Town } \\
\text { Major Town } \\
\text { Number of Women }\end{array}$ & $\begin{array}{c}1.00 \\
1.19 \\
1.42^{*} \\
6393\end{array}$ & $\begin{array}{r}\overline{2.50} \\
18.65\end{array}$ & $\begin{array}{l}1.00 \\
1.11 \\
1.55^{\star} \\
6393\end{array}$ & $\begin{array}{r}\overline{1.20} \\
20.65\end{array}$ \\
\hline
\end{tabular}

"Significant at 0.05 Level. 